\title{
In search of a new China: mineral demand in South and Southeast Asia
}

\author{
David Humphreys ${ }^{1}$ [D
}

Received: 30 June 2017 / Accepted: 3 September 2017 /Published online: 20 September 2017

(C) The Author(s) 2017. This article is an open access publication

\begin{abstract}
China's industrialisation transformed global markets for mineral commodities. As growth in China slows and becomes less material intensive, the question arises whether countries of South and Southeast Asia can take up the baton from China and give a further boost to global mineral demand. The economic prospects of South and Southeast Asia are undoubtedly promising, helped by growing populations and a fast-expanding middle class. However, the model of growth being embraced by these countries is different from that of China and likely to be less material intensive. Also, many of them are economically coming off a very low base. With respect to the supply of minerals to the region, the impact of India's growth on global mineral markets will be limited by the fact that many of India's mineral needs can be met from domestic sources. In Southeast Asia, some of the mineral requirements will be met from domestic resources while some of its requirements for finished metals will likely continue to be met from China which is a heavy investor in the region and which has massive surplus metallurgical capacity.
\end{abstract}

Keywords South and Southeast Asia $\cdot$ China $\cdot$ India $\cdot$ Mineral demand, mining, one belt one road

This article is dedicated to my dear friend Marian Radetzki whose relentless curiosity and infectious sense of fun have been a constant source of inspiration and enjoyment for me over 40 years in this intriguing business.

David Humphreys

dh@daiecon.net

1 CEPMLP, Dundee University, Dundee, UK

\section{Introduction}

Asia has reshaped the global demand for minerals over the past 20 years and is set to play a big part in shaping it over the next 20. International forecasting agencies suggest that economic growth and growth per head of population will be faster in Asia than in any other region. The population across South and Southeast Asia is also projected to grow strongly, while the middle classes of Asia should more than double over the period, contributing significant spending power. So understanding what is happening here is of crucial importance to the global mining industry.

\section{What is next after China?}

Up until now, the narrative of Asia's mineral demand growth has been wholly dominated by China. Driven by rapid industrialisation and urbanisation, China's demand for minerals soared, helping to trigger the largest commodity price boom of recent times. In the mid-1990s, China accounted for some $10-15 \%$ of global mineral demand. Twenty years later, it accounted for $50 \%$, a position of dominance unmatched since the US domination of global mineral markets in the years immediately following World War II.

Given this degree of dominance, what happens in China clearly remains extraordinarily important to the performance of metal and mineral markets. However, since 2010, China's economic growth rate has been slowing and government policies have been increasingly focused on trying to promote growth in domestic consumption and in services, which are, 
by their nature, less material intensive than exports and investment, the drivers of China's earlier growth. This is potentially a problem for suppliers of mineral raw materials.

Alongside closely monitoring China's economy, industry observers have begun to ask the question, what happens next? As demand from China slows, who will pick up the baton and drive things forward? Which countries should we be looking at if we are seeking to forecast future demand for minerals? In short, who, or where, is the next China?

India is the country most frequently mentioned in this context. It has a population very similar in size to China but an income per head (in PPP terms) almost 60\% lower-US\$6616 vs US\$15,399 in 2016 (IMF 2017) - so it has a lot of headroom for growth. The other countries of the India sub-continent, Pakistan, Bangladesh and Sri Lanka, represent a further 377 million people (Table 1). Also of growing interest economically are the countries of Southeast Asia, specifically the ten member countries of Asean (the Association of Southeast Asian Nations). Although the Asean countries are highly varied in terms of their income per head-ranging from rich Singapore to the very much poorer Cambodia - collectively they constitute another 638 million persons. In total, therefore, in South and Southeast Asia, one is looking at a region with a population of over 2.3 billion, almost a billion more than the population of China.

From the perspective of economic performance, as important as the size of a population is the composition of that

Table 1 South and Souteast Asia population and income per head in 2016

$$
\text { Population million }
$$

GDP/head US\$

Indian sub-continent

$\begin{array}{lll}\text { Bangladesh } & 161.5 & 3891 \\ \text { India } & 1309.3 & 6616 \\ \text { Pakistan } & 193.6 & 5106 \\ \text { Sri Lanka } & 21.3 & 12,262 \\ & 1685.7 & \\ \text { Asean } & & \\ \text { Brunei } & 0.4 & 76,884 \\ \text { Cambodia } & 15.8 & 3737 \\ \text { Indonesia } & 258.7 & 11,720 \\ \text { Laos } & 7.2 & 5710 \\ \text { Malaysia } & 31.7 & 27,267 \\ \text { Myanmar } & 523 & 5832 \\ \text { Philippines } & 104.2 & 7728 \\ \text { Singapore } & 5.6 & 87,855 \\ \text { Thailand } & 69.0 & 16,888 \\ \text { Vietnam } & 92.6 & 6429 \\ & 637.5 & \end{array}$

Source: IMF, WEO, April 17. GDP is based on purchasing power parities (PPPs) population. One aspect of this is the population's age structure and the proportion of the population available to the labour force. Through much of South and Southeast Asia, and in contrast to China, populations are young and the proportion of the population accounted for by working-age people is rising. More than half of Asean's population is under the age of 30 (Asean Secretariat 2017). This is a hugely positive indicator for future economic growth.

Another aspect is the growth in the proportion of the population deemed middle class. The definition of what constitutes middle class varies, but generally it covers those having a daily income in the range US\$10-US\$100 a day (Yueh 2016). It is typically the case that as incomes rise above a certain point then consumers are relieved of having to devote their entire income to buying essentials with the result that a disproportionate amount of any income above this level is spent on consumer durables. Historically, this has proven highly supportive of mineral demand.

The last point, and it is an important one, is that a number of countries in South and Southeast Asia have in recent years elected, or else acquired by other means, business-friendly governments which have set themselves the objective of using their competitive labour forces as a platform for boosting the living standards of their peoples through the encouragement of enterprise and the flow of inward investment. The economic potential of this region and the possibilities offered by regional integration to boost this potential still further currently constitutes the most compelling growth story in the world.

The remainder of this article takes a closer look at the economies of South and Southeast Asia and what their future growth might imply for mineral commodity markets.

\section{India's growth prospects}

For much of the last 20 years, growth in the Indian economy has lagged behind that of China. However, this is changing. Since 2015, GDP growth in India has begun to push ahead of that in China and projections by international agencies such as the IMF show the gap between growth rates in the two countries widening (in India's favour) in coming years (Fig. 1).

The reasons behind this are several fold. A key driver of GDP growth is population, and India's population growth is significantly outstripping China's. India's population is currently growing at $1.3 \%$ a year against China's $0.4 \%$. According to the UN Population Division, India's population will overtake China's in 2022 (UN 2017). Even more importantly from an economic perspective, the same data source shows the proportion of India's population of working age rising until the 2030s while China's, largely because of its one child policy, started to decline in 2015.

A second factor is simply that India is coming off a much lower base than China. One of the key factors driving growth 
Fig. 1 Economic growth in India and China. Source: IMF, WEO, April 2017

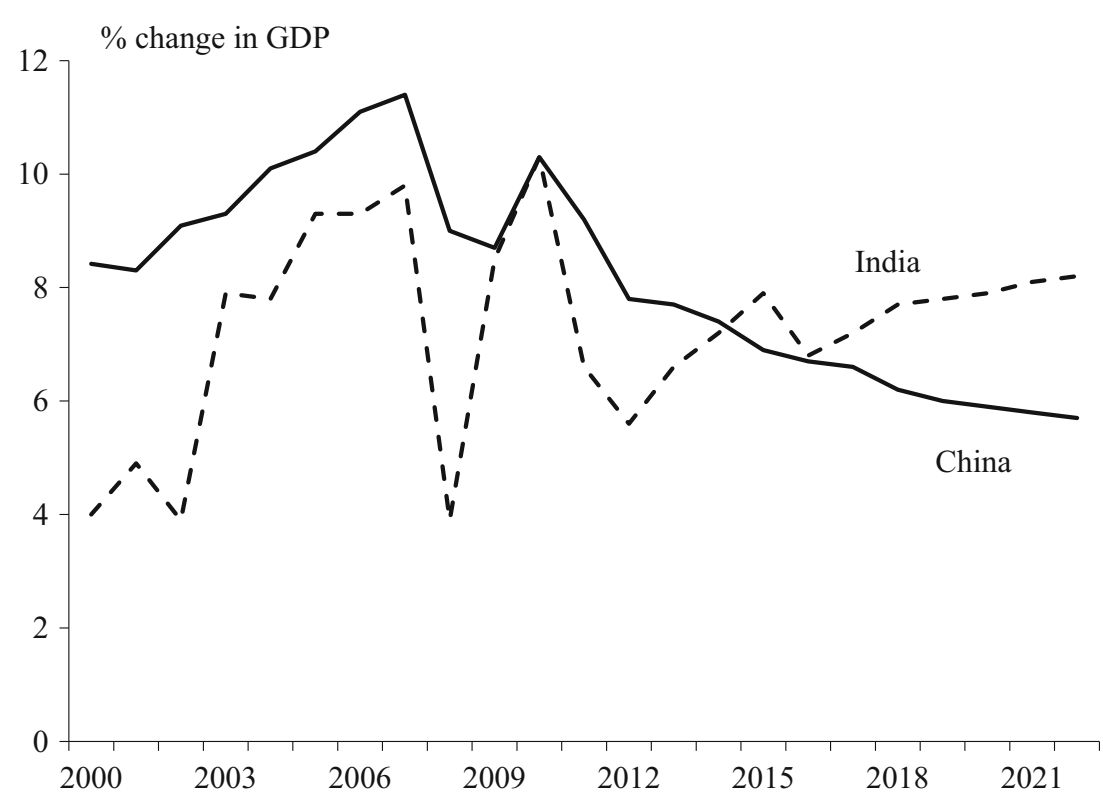

in emerging economies is their capacity to rapidly increase productivity by importing technologies and work practices from elsewhere, in other words, to exploit the opportunities of economic catch-up. As the gap with technologies and work practices employed elsewhere diminishes, and as local wage costs rise, so rapid productivity growth becomes harder to sustain. China is facing this reality now. India has a long way to go before this becomes a problem.

The other factor, already alluded to above, is the prospective growth in the middle class. Growth in India's income per head in coming years is expected to dramatically expand its middle class, and, with it, the country's demand for improved residential properties and consumer durables. This is not just significant at a national level, it has global significance too. Research by The Brookings Institution indicates that between 2015 and 2030, the global middle class will grow from 3 million to 5.4 million. Much the biggest contributor to this growth will be Asia with an increase of 2.1 million. Within that Asian number, the biggest increase will come from India. By 2030, India will have a middle class similar in size numerically to that in China. In terms of consumer spending power (PPP based), it is estimated that India's middle classes will account for $17 \%$ of the global total, and will be second only to China, at 22\% (Kharas 2017).

On the face of it, this suggests a very positive outlook for mineral demand in India. But India is not China. And comparisons between the two countries are not straightforward.

\section{Comparisons with China}

The difference between China's and India's use of minerals is far greater than can be accounted for by the relative sizes of their GDP. While India's GDP is currently $40 \%$ that of China, its use of minerals is only $5-10 \%$ that of China's, at least for industrial metals (Fig. 2). Gold is a bit different as discussed below.

The simple fact is that China's recent growth has been unusually material intensive, and that, by comparison with most other countries, India included, it uses far more mineral raw materials per unit of economic growth. Figure 3 shows how much more metal China uses in generating a million dollars of GDP than India. For example, China uses eight times as much aluminium to generate a million dollars of GDP than does India.

It has long been understood that the stage of a country's development has important implications for its use of mineral raw materials (Malenbaum 1978). As an economy moves from an agricultural to an industrial basis, its use of materials accelerates rapidly, with rates of materials' use typically outstripping - sometimes substantially - the rate of growth in

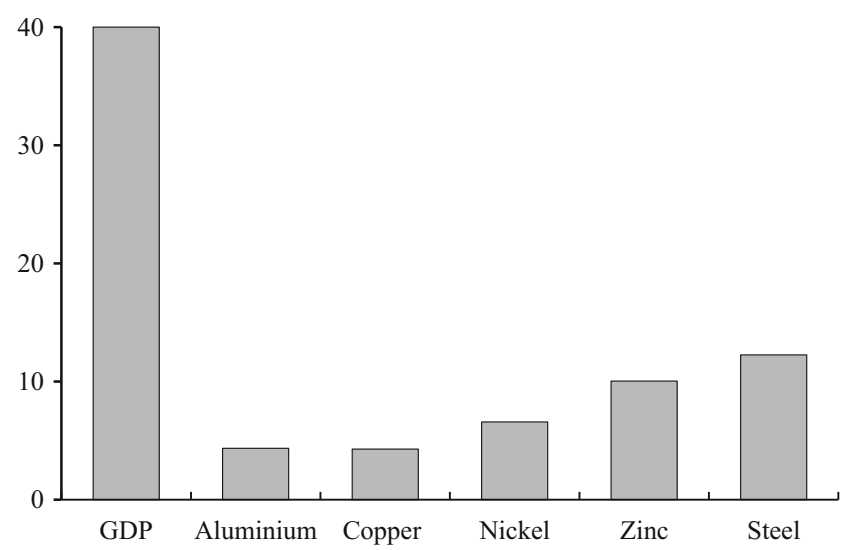

Fig. 2 India's GDP and use of metals as a percentage of that in China 2015. Source: IMF, WBMS, WSA 


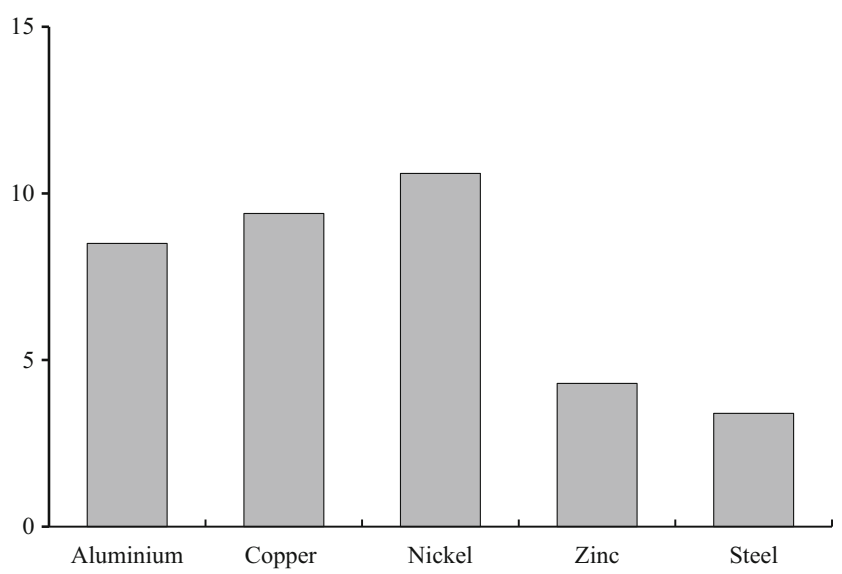

Fig. 3 Metal use per US\$ million of GDP: ratio of China to India. Source: IMF, WBMS, WSA

the economy as a whole. As an economy matures, and development becomes more focused on service sector activities, so the material intensity of economic growth diminishes. The stylised version of this process shows mineral raw material use of a country progressing in an elongated S-shaped fashion.

In practice, there is significant variation between countries in how this model applies (Crowson 2017). Small industrialised export-oriented countries like South Korea and Taiwan show unusually high levels of material use, while countries whose competitive advantages lie in producing raw materials rather than manufacturing, like Australia and Canada, follow a flatter path. Although a continental-scale economy, China's use of mineral raw materials has, up to now, followed a path surprisingly close to that of its smaller Asian neighbours.

Part of the explanation for this is structural. China's growth has over the past 20 years given emphasis to exports of manufactured goods and to the infrastructure and plant necessary to support the growth of these exports. It has thus had to build not just the factories to make manufactured goods and to supply them with raw materials, but has had to build the roads, railways, ports, airports, power stations and power networks to supply those factories and carry their goods away, as well as building accommodation and services for the many millions of people flowing from the countryside to the cities to work in the factories.

The effects of this can be seen in the composition of China's economy. Although the service sector in China has latterly been growing fast, $40 \%$ of its GDP is still accounted for by industry. In India, the share is just under 30\%. India's agricultural and service sectors are commensurately larger (at 17 and 54\% of GDP respectively). While in China exports are equivalent to $19 \%$ of GDP, in India the proportion is only $12 \%$. India's economy is thus more domestically driven (World Bank 2017).

Levels of investment are another point of difference between the two countries. Looking at GDP from the perspective of expenditure, it is clear that investment in China's economy represents a much higher proportion of GDP than is the case in India. Since 2003, China's investment as a share of GDP has averaged $44 \%$, at the peak of the boom rising to $48 \%$. In India, investment as a proportion of GDP has averaged $35 \%$, a figure more in line with the average of other emerging economies in Asia, but well below China (Fig. 4). In short, India has pursued a rather different, and significantly less mineral intensive, form of growth than China.

While it is likely that India's economic growth will continue to contribute to growth in future global mineral demand, the chances of it following the pattern of mineral use in China are slim. The focus of growth is likely to continue to be on the domestic economy. Private consumption accounts for almost $60 \%$ of India's GDP against less than $40 \%$ in China. As a democracy, it is less practical for India to prioritise export growth over domestic demand and then salt away the gains from this in foreign exchange reserves under the control of the state as occurred in China. Growth has to be more socially inclusive. It is also likely that India will continue to give emphasis in its growth to agriculture and to service sector activity, the former for political reasons, the latter because this is an area where India has been highly successful in establishing global competitive advantage, helped by the less burdensome regulation of the service sector compared with manufacturing and by the widespread use of the English language in the country. India, in short, is unlikely to follow the same pattern of industrialisation as China (Nageswaran and Natarajan 2016).

Another point of difference is that India does not have China's capacity for top-down, central economic direction. Availability of financial resources along with the need to maintain a fragile political consensus restricts the ability of the government in India to promote centrally directed investment-led growth. Its economically more liberal model requires a more demand-led approach, one that gives primary emphasis to encouraging the bottom-up growth of private, often family, businesses, and domestic consumer demand. The ability of the government to direct the economy centrally is also restricted by the fact that states in India have very significant economic discretion (Anand 2013). Thus, while it may be true that India desperately needs massive investment in infrastructure - and the government has many initiatives to promote such investment, including a US\$60 billion commitment to infrastructure in the February 2017 budget - the complexities of government in India and the reality that such infrastructure building tends to come in response to demonstrated economic need rather than anticipated future requirements (as is often the case in China) makes it unlikely that India will emulate China's sky-high levels of investment.

A particular area of promise for mineral demand in India follows directly from the rapid growth in its middle class. Given its different social-economic structure, Indian citizens are likely to be able to retain a higher proportion of national 
Fig. 4 Investment's share of GDP. Source: IMF

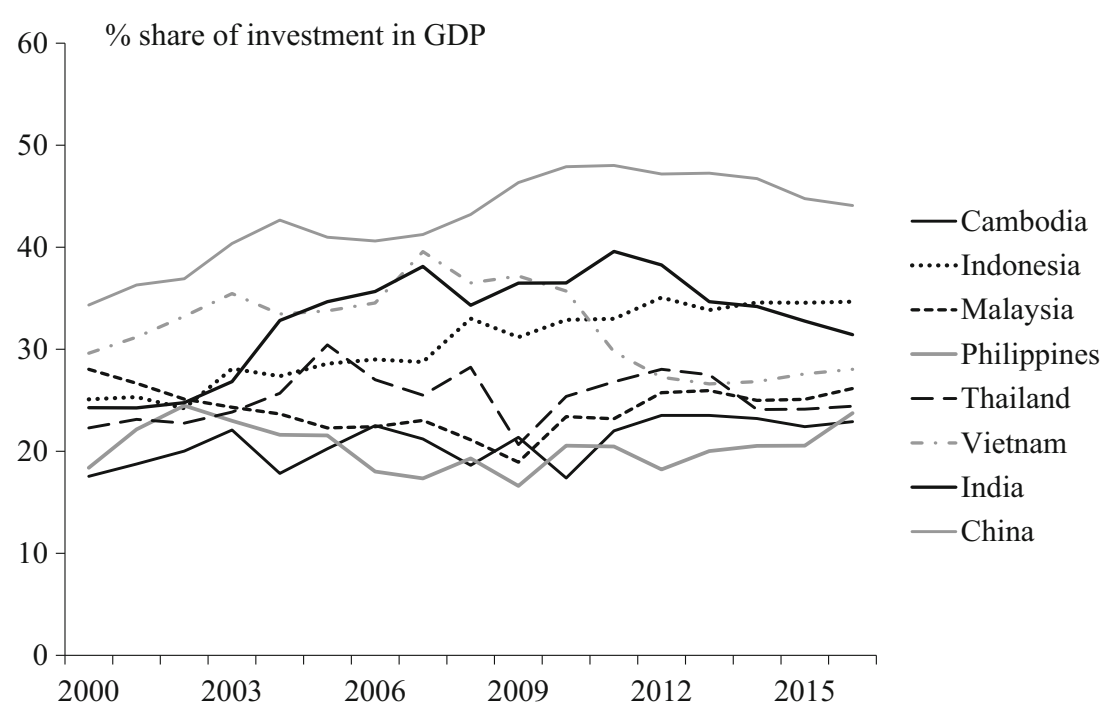

income for personal expenditure than has typically been the case in China. And, as noted above, as incomes rise, so discretionary spending on consumer and luxury goods increases at a proportionately faster rate.

One commodity where India is already a major global consumer is gold. Although it varies year to year which country is the largest consumer of gold, between them India and China account for around half the world's demand for gold for fabrication. For cultural and economic reasons, India has long been one of the world's biggest buyers of gold. Indians like gold as a store of value but also for gift-giving and as an adornment. As India's middle class grows and disposable incomes rise, so there is potential for this market to grow significantly further — or so the World Gold Council believes at least (WGC 2017).

\section{Sourcing India's mineral raw materials}

To assess the likely impact of India's economic growth on global mineral markets, it is necessary to consider India's resource endowment and how much of its growing demand for minerals it is likely to be able to supply from domestic sources.

Part of China's impact on global mineral markets arose from the fact that for certain key minerals necessary for its industrialisation, China's domestic mineral resources are somewhat limited, requiring it to turn to international markets for supplies. Thus, for commodities such as iron ore, bauxite, copper and nickel, China's demand has had a dramatic effect on global markets and on mine producers in other parts of the world.

India can generally be considered a mineral-rich country, although, as with China, it inevitably has some gaps in its endowment. Given the relatively low levels of its mineral use in the past, it has not on the whole needed to rely too heavily on imported supplies (Table 2). It has also traditionally been somewhat protectionist in its thinking, preferring selfsufficiency where it could be achieved, and history offers several instances where India has discouraged exports of minerals for fear of running down its domestic resources and also of encouraging the use of minerals which occur locally over those which have to be imported.

India is reasonably well endowed with iron ore, having $6 \%$ of the world's iron ore reserves by iron content according to the US Geological Survey (USGS 2017). For years, the government has restricted the export of India's better-quality ores (notably those from Bailadila) on the grounds that they are, or will be, required for domestic steel production. In more recent years, India's exports of lower-quality iron ore rose rapidlyfrom 31 million tonnes in 1999 to 101 million tonnes in 2008 (WSA 2016) - to meet China's burgeoning demand for imported ore before falling away sharply as the government intervened to constrain these exports, this on the grounds that a lot of the trade was being conducted by unregulated and environmentally destructive operators.

India is significantly less well-endowed with copper resources. Historically, this led the country to discourage the use and import of the metal, and to encourage instead the use of aluminium, where India was better endowed. With copper such a critical metal in so many modern electrical and electronic applications, this was clearly sub-optimal economically and in recent years India has relaxed its attitude to copper imports. India, like China, has become a major importer of copper concentrates for processing in its domestic smelters and refineries. The Indian mining company, Vedanta, has also sought to bolster the country's access to copper by investing in copper overseas, most notably in the Konkola copper mining and smelting operations in Zambia.

Amongst other metallic minerals, India has substantial resources of bauxite. Based on these, it has long had an aluminium industry and the country is typically a net exporter of 
Table 2 Mineral balances for India in 2016

\begin{tabular}{lllll}
\hline & Mine prod. & Metal prod. & Consumption & Prod-cons \\
\hline Aluminium & $24.2 \mathrm{Mt}$ bauxite & $1909.1 \mathrm{kt}$ & $1377.6 \mathrm{kt}$ & $+531.5 \mathrm{kt}$ \\
Copper & $27.6 \mathrm{kt}$ copper & $768.2 \mathrm{kt}$ & $499.3 \mathrm{kt}$ & $+268.9 \mathrm{kt}$ \\
Lead & $138.9 \mathrm{kt} \mathrm{lead}$ & $508.3 \mathrm{kt}$ & $566.8 \mathrm{kt}$ & $-58.5 \mathrm{kt}$ \\
Nickel & - & $0.3 \mathrm{kt}$ & $57.4 \mathrm{kt}$ & $-57.1 \mathrm{kt}$ \\
Zinc & $649.0 \mathrm{kt}$ zinc & $611.8 \mathrm{kt}$ & $672.4 \mathrm{kt}$ & $-60.6 \mathrm{kt}$ \\
Iron ore/steel & $178.6 \mathrm{Mt}$ iron ore & $95.6 \mathrm{Mt}$ & $83.5 \mathrm{Mt}$ & $+12.1 \mathrm{Mt}$ \\
Coal & 288.5 oil equiv & & $411.9 \mathrm{oe}$ & $-123.4 \mathrm{oe}$ \\
Gold & - & & $16.3 \mathrm{m.oz} \mathrm{fabr}$ & \\
Silver & 14 million oz & & $163.4 \mathrm{m.oz} \mathrm{fabr}$ & \\
\hline
\end{tabular}

Source: WBMS, WSA, BP, GFMS, Silver Institute aluminium. A broadly similar situation exists for lead and zinc where India is a world-class producer and where domestic mine and metal production are usually (albeit not in 2016) sufficient to meet domestic market requirements.

For other commodities, India is less well endowed. India is not a major producer of nickel, and most of the nickel required for its large stainless steel industry has to be imported in the form of refined nickel or ferronickel. India is almost wholly reliant on imports for its substantial requirement for gold and platinum group metals, but it has a modest production of silver. For coal, the situation is a bit more complex. While India has substantial domestic resources of thermal coal, some of this coal is of poor quality and needs to be blended with higher-quality coal from elsewhere, so the country is typically a net importer. For coking coal, used in its steel industry, India has limited local resources and is a significant importer.

The impact of India's growing demand for mineral products on global mineral markets is thus likely to be mixed amongst commodities, with the biggest impacts likely to be felt in the markets for copper, nickel, precious metals and coking coal.

\section{Economic development in Southeast Asia}

As a large and diverse region, Southeast Asia is rather harder to generalise about than India with respect to its mineral requirements and mineral endowment. The region includes large resource-rich countries like Indonesia and the Philippines, resource-poor but otherwise rich city states like Singapore and countries in the early stages of their economic development like Myanmar, Cambodia and Laos. There are also significant differences in the politics of the countries, some being democratic, some avowedly communist and some authoritarian.

The economic outlook for the region is considered, however, to be prospectively very promising as noted earlier. Along with India, the IMF sees the Asean 5 (Indonesia, Malaysia, Philippines, Singapore and Thailand) as the fastest-growing region in the world over the period to 2022. The other Asean countries, those often referred to as the CLMV countries (Cambodia, Laos, Myanmar and Vietnam), are, however, forecast to grow even faster (Table 3) (Note that the tenth member of Asean, Brunei, has been excluded from this analysis.). The potential of the Asean region is considered massive.

CLMV countries have an aggregate population of 170 million and, with wages significantly below those in China, have begun to draw manufacturing industry away from the China mainland. Moreover, whatever the ostensible differences in their politics, most governments in the region are keen to present themselves as business-friendly and supportive of industry and enterprise. Exports from the region are growing strongly. According to the Asean Secretariat, total trade in the region increased by US $\$ 700$ billion between 2007 and 2015 with intra-Asean trade comprising the largest share of total Asean trade (Asean Secretariat 2017). As these data imply, this is also a story about regional economic integration.

While the USA has shown its disinterest in further deepening its trade relationships in the region with its withdrawal from the Trans-Pacific Partnership (TPP), this is likely simply to create a bigger opportunity for other countries, including China, to step up their role as trade leaders in the region. Quite

Table 3 Forecast GDP growth in India and in Asean

\begin{tabular}{lccccccc}
\hline & 2016 & 2017 & 2018 & 2019 & 2020 & 2021 & 2022 \\
\hline India & 6.8 & 7.2 & 7.7 & 7.8 & 7.9 & 8.1 & 8.2 \\
Indonesia & 5.0 & 5.1 & 5.3 & 5.4 & 5.5 & 5.5 & 5.5 \\
Malaysia & 4.2 & 4.5 & 4.7 & 4.9 & 4.9 & 4.8 & 4.8 \\
Philippines & 6.8 & 6.8 & 6.9 & 7.0 & 7.0 & 7.0 & 7.0 \\
Singapore & 2.0 & 2.2 & 2.6 & 2.6 & 2.6 & 2.6 & 2.6 \\
Thailand & 3.2 & 3.0 & 3.3 & 3.2 & 3.1 & 3.0 & 3.0 \\
Asean-5 & 4.9 & 5.0 & 5.2 & 5.3 & 5.3 & 5.3 & 5.3 \\
Cambodia & 7.0 & 6.9 & 6.8 & 6.8 & 6.5 & 6.3 & 6.3 \\
Lao PDR & 6.9 & 6.8 & 6.7 & 7.0 & 6.9 & 7.0 & 6.7 \\
Myanmar & 6.3 & 7.5 & 7.6 & 7.5 & 7.5 & 7.5 & 7.5 \\
Vietnam & 6.2 & 6.5 & 6.3 & 6.2 & 6.2 & 6.2 & 6.2 \\
\hline
\end{tabular}

Source: IMF, WEO, April 2017 
separate from the TPP, there is currently an Asean-led discussion on multilateral trade liberalisation, entitled Regional Comprehensive Economic Partnership (RCEP), taking place across the wider region. Unlike the TPP, this initiative includes China. Asean has also been seeking to promote integration within the Asean region through initiatives of the Asean Economic Community (AEC). These include a package of measure entitled AEC Blueprint 2025, adopted by the Asean leaders at their summit in Kuala Lumpur in November 2015.

Investment is the key to sustaining the region's growth outlook. The Asian Development Bank says Southeast Asia needs to spend US\$210 billion a year to 2030 (5.7\% of GDP) on infrastructure (defined as transport, power, telecommunications, water supply and sanitation) if it is to maintain its growth, tackle poverty and deal with the effects of climate change (ADB 2017). Fortunately, levels of public debt across Asean are low by international standards (the average across the region is $39 \%$ of GDP), leaving central and local government free to borrow to invest in much-needed infrastructure without unduly squeezing out private investment. Some of the targets for infrastructure building are ambitious. The Indonesian government is committed to a large programme of infrastructure building, with plans over 3 years (starting 2016) to build 35,000 MW of electricity generating capacity, $2850 \mathrm{~km}$ of new roads and $3200 \mathrm{~km}$ of railways, together with new seaports and airports. The Philippines in 2016 increased infrastructure spending to the high level of 5\% of GDP. In Thailand, it is claimed that some US $\$ 51$ billion of infrastructure projects will be underway before 2018. By 2020, Malaysia will have invested another US $\$ 44$ billion in upgrading transport links and in building new roads and railways.

The situation with respect to foreign direct investment (FDI) is equally positive. North Asia, which is to say, China, Japan and South Korea, enjoys a surfeit of capital, and significant amounts of this capital are being directed towards the capital-poor but labour-rich countries in the south of Asia where returns on capital are prospectively greater and markets are seen as having substantial potential for growth. Between 2012 and 2015, around US\$120 billion a year of net FDI flowed into Asean, of which $40 \%$ was accounted for by investment coming from countries of North Asia (Asean Secretariat 2017). Major recipients of this FDI in 2015 were, according to UNCTAD, Singapore (US\$65bn), Indonesia (US\$16bn), Malaysia (US\$11bn), Thailand (US\$11bn) and Vietnam (US\$12bn) (UNCTAD 2016). Some of these investments are of a sizeable scale. Vietnam in April 2017 acquired its second billion dollar investment, the Japanese-backed LotB-O Mon gas pipeline project in Kien Giang province. The first was Samsung Display's investment in Bac Ninh province (VietNamNet 2017).

A large boost to the cause of regional economic integration and to regional growth is expected to be provided by China's 'one belt, one road' (OBOR) initiative, launched in 2013. This comprises a massive infrastructure programme to connect China with Europe overland through central Asia and to connect China's maritime routes to east Africa and the Middle East through to the Mediterranean. While the project is touted as an opportunity to use China's own development experience to leverage development in adjacent economies, it is obviously also an opportunity for Chinese businesses to draw benefit from the lower labour costs in Southeast Asia, to create new markets for its own goods and services and for the country to project its political and military influence in Asia.

The scale of OBOR is significant. As of mid-2017, some US\$900 billion worth of FDI infrastructure projects were in construction or in detailed planning under the OBOR programme according to the China Development Bank. In 2015, a record year for China outward FDI, with a total FDI spend of US $\$ 146$ billion, investment in OBOR countries showed a 39\% increase on 2014 (Xinhua 2016). The effect of this expenditure should be to knit large tracts of Asia together economically and also to provide access to markets further west. The maritime 'road' passes through the South China Sea and up into the Bay of Bengal, and incorporates two the OBOR's six development 'corridors', the China-Indochina Peninsula Corridor and the Bangladesh-China-India-Myanmar Corridor.

The countries of Southeast Asia are generally embracing the opportunity which the OBOR programme creates. In view of its geographic location, greater economic maturity and its large ethnic Chinese minority, Thailand has been busy positioning itself as the hub of CLMV trade and investment and as the gateway to China's development 'road' (Theparat 2017). On the Indian sub-continent, Pakistan's response has also been positive with the leadership of Pakistan's mineral-rich Baluchistan province welcoming OBOR as an opportunity to have China assist with the opening up of its undeveloped mineral resources (Yousufzai and Jorgic 2017). India, unsurprisingly, is much less comfortable with China's political growing influence throughout the region.

\section{Raw materials for Southeast Asia}

The rate of future growth in Southeast Asia will be key to determining its mineral raw material requirements as will the composition of that growth. Clearly, the large amount of money being committed to investment in infrastructure will be a driver of mineral demand, as will growth in the region's manufacturing industries and the development of its real estate market.

For the present, the region is a relatively modest user of mineral commodities, its combined consumption of steel and aluminium, for example, being similar to that in India (at 5 and $3 \%$ of global demand respectively). However, as in India, demand is on a rising trend (Fig. 5). Growth in the regional use of steel has averaged $7.5 \%$ a year in the last decade while 
Fig. 5 Metal demand in the Asean region. Source: WBMS, WSA

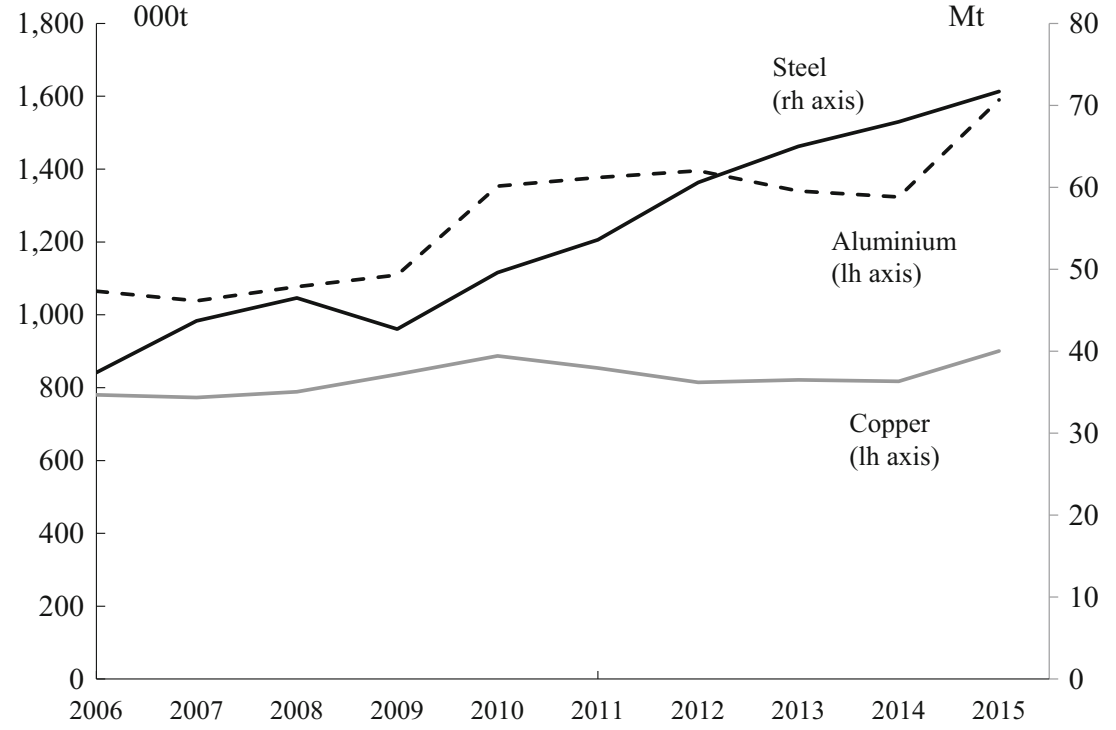

growth in the use of aluminium has averaged $4.5 \%$. Copper growth has been slower (1.5\%). This may be because of differences in end uses (steel and aluminium are more heavily employed in construction) or because copper imports to the region have been entering in the form of copper semimanufactures as opposed to unwrought refined metal. The major consumers of these products within the region are, roughly in order of scale, Indonesia, Thailand, Malaysia and Vietnam. Clearly there is some way to go before demand in Asean will be able to exercise a major impact on global markets. But there is no doubting the economic vibrancy of the region or its potential.

Given the number of countries involved and the differences between them, the issue of raw materials supply to the region is complex.

Indonesia is a major producer and exporter of mineral commodities. In addition to being one of the world's largest producers of coal, Indonesia is a significant producer of copper, nickel, gold, tin and bauxite. The decision of the Indonesian government to ban the export of unprocessed minerals in 2014 unsurprisingly frightened off many foreign investors, but Chinese companies took the opportunity to increase their investment in the local production of nickel, aluminium and electrical power. Mining elsewhere in the Asean region is generally on a smaller scale, although there is mine production in the Philippines (notably copper, nickel and gold), Malaysia (tin and bauxite), Vietnam (coal, bauxite, copper and tin), Myanmar (tin and copper), Laos (copper and nickel) and Thailand (zinc and tin).

In the northern part of Asean, which is to say in the CLMV countries, although there may well be scope for increased mine production, the emerging economic model appears to be more focused on manufacturing activity and in keying this manufacturing into the supply chains of the more northerly parts of Asia. For which reason, it may well follow the development pattern of the countries of North Asia and import the greater part of its raw material requirements.

Of some interest in this regard is what is happening with steel. With the demand for steel in the Asean countries rising at $7.5 \%$ a year over the past decade, it might be expected that production of steel in the region would have grown commensurately. However, it has not; it has grown scarcely at all. Asean steel production is around 20 million tonnes a year against a consumption of 70 million tonnes a year.

In fact, the greater part of Asean's demand for steel is being met by imports from China (Fig. 6). Of the 50 million tonnes which the region was required to import in 2016, 40 million tonnes was sourced from China, the biggest importers being Vietnam (11.7 million tonnes), Philippines (6.5 million tonnes), Thailand (6.2 million tonnes) and Indonesia (5.8 million tonnes). Collectively, Asean was China's largest export market for steel.

There is some logic to this. Steel-making benefits from economies of scale and building small high-cost steel plants to meet the relatively limited demand arising in local markets is not particularly attractive when China's low-cost, large-scale steel producers to the north have substantial overcapacity. It may be that for some time to come this will represent a pattern for other metals such as aluminium too, with China using its massive might in mineral raw material markets to furnish supplies to its low-wage neighbours in the south, particularly since some of these investors will be other Chinese companies. ${ }^{1}$

\footnotetext{
${ }^{1}$ This said, Vietnam's steel market has now grown to a size when it can support a large local steel producer and Formosa Plastics in 2017 started up a large (22 million tonnes a year) steel mill in central Ha Tinh province.
} 
Fig. 6 Exports to Asean as a percentage of Chinese total steel exports. Source: China Customs

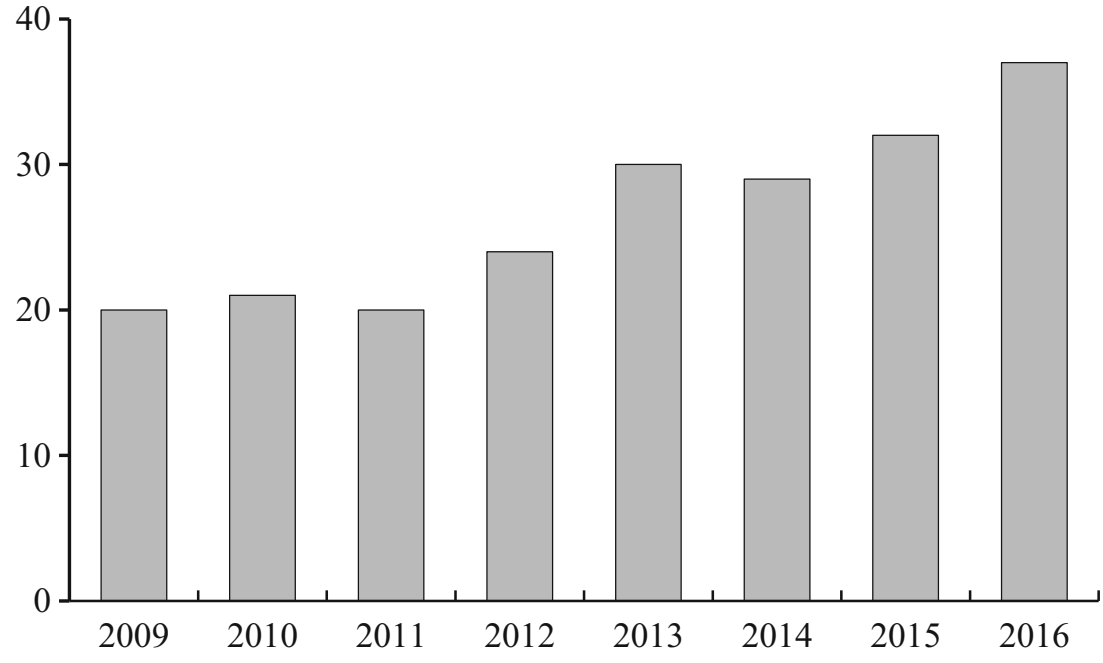

This may represent the pattern for OBOR investment too. Given that most of the money for OBOR projects is coming from China and that a big role will be played by Chinese contractors in building out the infrastructure under the programme, it may be assumed that many of the mineral raw materials required for these investments will be sourced from China.

\section{Concluding remarks}

The development and economic integration of South and Southeast Asia is arguably the most interesting growth story in the world today. Although comprising countries highly disparate in their nature, and although obviously lacking the economic cohesion of China, collectively the region has simply enormous untapped economic potential. It will undoubtedly become a growing force in the global economy and take up part of the running in driving the global economy as China's domestic economy matures and slows.

However, it looks improbable that the growth of South and Southeast Asia will have the same impact on global mineral markets as China, at least not for many years to come. This is partly because, for the moment at least, the size of these economies is dwarfed by China and partly because of the lesser mineral intensity of these economies. The relative scale of demand for selected metals is vividly illustrated in Fig. 7. While it certainly is the case that Asia is now the key regional market for minerals, with two thirds of total global demand, demand in South and Southeast Asia will have to travel a long way to represent a major offset to market developments in China and to achieve a number of years of the sort of double-digit demand growth that marked China's industrialisation.

In fact, China's model of raw material demand growth may not be wholly relevant to how mineral markets develop in
South and Southeast Asia. It could be that the major mineral and metallurgical powerhouses in the region, certainly China, but perhaps India and Indonesia also, will use their resource endowments and scale to furnish many of the mineral raw materials that the other countries in the region will require for their industrialisation, removing the incentive for countries more focused on manufacturing to establish their own metallurgical and semi-fabricating industries. The competitive advantage of many of these economies, after all, lies more in low-wage manufacturing and services than in geologically dependent, energy-intensive, mineral production.

The switch in the focus of Chinese investment from the domestic arena towards FDI may not much change things either. This is partly because the scale of the outward investment, although unquestionably large, is nonetheless modest by comparison with the massive growth of China's domestic investment which drove the commodity boom in the 2000s (Robertson 2017). Moreover, much of the mineral consumption stimulated by the OBOR

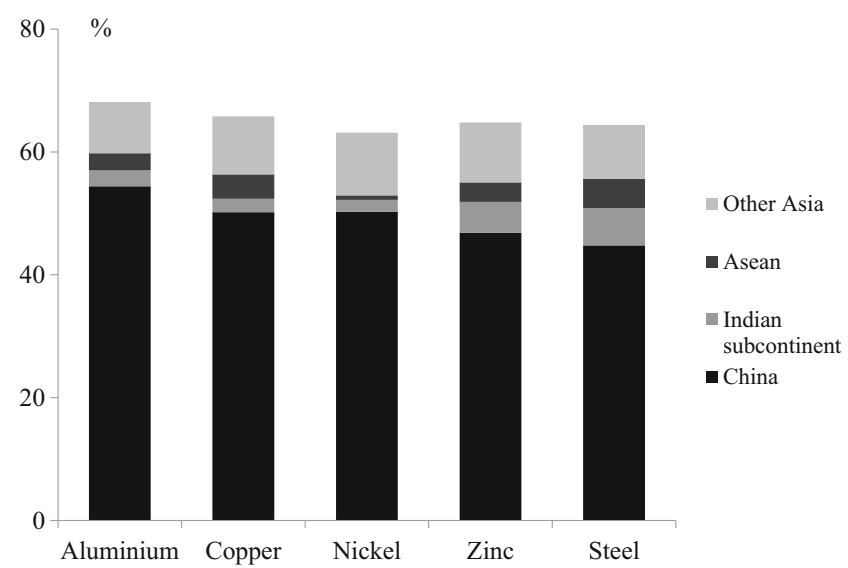

Fig. 7 Non-Japan Asia's share of global demand for selected metals, 2015. Source: WBMS, WSA 
programme may report as increased consumption in China rather than in the countries where the investment is actually taking place, since it is likely that China will supply a lot of the raw materials for the investment.

In short, although the South and Southeast Asian region holds really positive implications for future mineral raw material markets, it may not be quite the next 'big thing' that many in the mining industry might be hoping for. More than ever, it seems that China's extraordinary impact on mineral markets in the 2000s was a one-off event. There is no new China.

Open Access This article is distributed under the terms of the Creative Commons Attribution 4.0 International License (http:// creativecommons.org/licenses/by/4.0/), which permits unrestricted use, distribution, and reproduction in any medium, provided you give appropriate credit to the original author(s) and the source, provide a link to the Creative Commons license, and indicate if changes were made.

\section{References}

ADB (2017) Meeting Asia's infrastructure needs Available at: www.adb.org Anand M (2013) Toward a uniquely Indian growth model, McKinsey\&Company, http://www.mckinsey.com

Asean Secretariat (2017) Asean website http://asean.org

BP (2017) Statistical review of world energy. Available at: www.bp.com Crowson P (2017) Intensity of use re-examined. Miner Econ. https://doi. org/10.1007/s13563-017-0113-Z

GFMS (2017) Gold survey 2017. Thomson Reuters, New York

IMF (2017) IMF World Economic Outlook database Available at: www. imf.org
Kharas H (2017) The unprecedented expansion of the global middle class; an update, The Brookings Institution

Malenbaum W (1978) World demand for raw materials in 1985 and 2000. McGraw-Hill, New York

Nageswaran VA, Natarajan G (2016) Can India grow? Challenges, opportunities, and the way forward, Carnegie India Available at: http:// carnegieindia.org

Robertson J (2017) Better than nothing, but not enough. Min Journal 2 June 2017, p 17.

Silver Institute (2017) World silver survey 2017. Thomson Reuters, New York

Theparat C (2017) Somkid urges Thai-CLMV master plan, Bangkok Post. Available at: www.bangkokpost.com. Accessed 24 March 2017

UN (2017) UN Population Division statistics. Available at: http://www. un.org/en/development/desa/population/

UNCTAD (2016) World investment report. Available at: http://unctad.org

USGS (2017) Mineral commodity summaries. US Geological Survey, Reston

VietNam Net (2017) Second billion-dollar FDI project licensed, 2 May 2017. At: http://english.vietnamnet.vn/

World Bank (2017) World development indicators. Available at: http:// data.worldbank.org/data-catalog/world-development-indicators

WBMS (n.d.) World Metal Statistics Yearbook, various editions

WGC (2017) India's gold market: evolution and innovation. World Gold Council, London

WSA (2016) Steel statistical yearbook 2016 and other editions. World Steel Association, Brussels

Xinhua (2016) China's Investment in belt and road countries up 38.6\%, China Daily Asia. Available at: http://www.chinadaily.com. Accessed 22 Sept 2016

Yueh L (2016) The rise of the global middle class. www.bbc.co.uk. Accessed 19 June 2013

Yousufzai G, Jorgic D (2017) Pakistan to open up mineral-rich Baluchistan to China 'silk road' firms. Inside Metals, Thomson Reuters. Available at: http://uk.reuters.com. Accessed 5 June 2017 